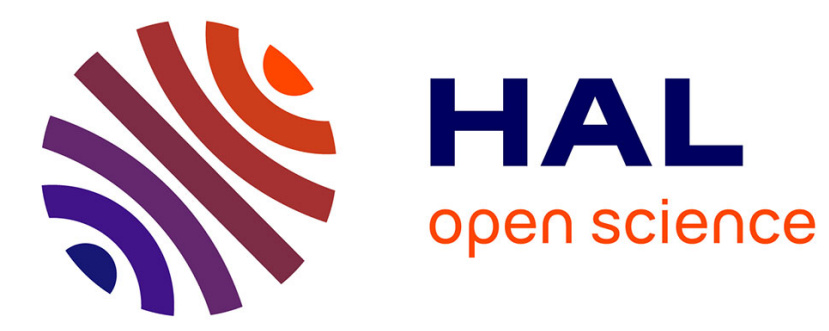

\title{
Human microvascular endothelial cells are sensitive to IGF-I but resistant to insulin at the receptor level
}

\author{
G.S. Johansson, S.I. Chisalita, H.J. Arnqvist
}

\section{To cite this version:}

G.S. Johansson, S.I. Chisalita, H.J. Arnqvist. Human microvascular endothelial cells are sensitive to IGF-I but resistant to insulin at the receptor level. Molecular and Cellular Endocrinology, 2008, 296 (1-2), pp.58. 10.1016/j.mce.2008.07.012 . hal-00532054

\section{HAL Id: hal-00532054 https://hal.science/hal-00532054}

Submitted on 4 Nov 2010

HAL is a multi-disciplinary open access archive for the deposit and dissemination of scientific research documents, whether they are published or not. The documents may come from teaching and research institutions in France or abroad, or from public or private research centers.
L'archive ouverte pluridisciplinaire HAL, est destinée au dépôt et à la diffusion de documents scientifiques de niveau recherche, publiés ou non, émanant des établissements d'enseignement et de recherche français ou étrangers, des laboratoires publics ou privés. 


\section{Accepted Manuscript}

Title: Human microvascular endothelial cells are sensitive to

IGF-I but resistant to insulin at the receptor level

Authors: G.S. Johansson, S.I. Chisalita, H.J. Arnqvist

PII: $\quad$ S0303-7207(08)00308-0

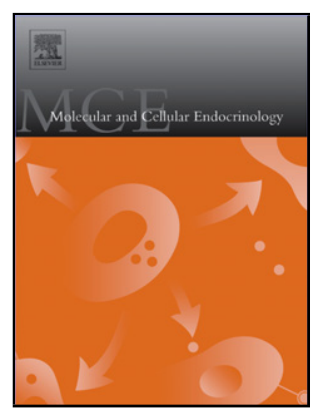

DOI: doi:10.1016/j.mce.2008.07.012

Reference: MCE 6925

To appear in: Molecular and Cellular Endocrinology

Received date:

23-6-2008

Revised date: 15-7-2008

Accepted date: 16-7-2008

Please cite this article as: Johansson, G.S., Chisalita, S.I., Arnqvist, H.J., Human microvascular endothelial cells are sensitive to IGF-I but resistant to insulin at the receptor level, Molecular and Cellular Endocrinology (2007), doi:10.1016/j.mce.2008.07.012

This is a PDF file of an unedited manuscript that has been accepted for publication. As a service to our customers we are providing this early version of the manuscript. The manuscript will undergo copyediting, typesetting, and review of the resulting proof before it is published in its final form. Please note that during the production process errors may be discovered which could affect the content, and all legal disclaimers that apply to the journal pertain. 
MCE-D-08-00188

Human microvascular endothelial cells are sensitive to IGF-I but resistant to insulin at the receptor level
REVISED MANUSCRIPT

Git Johansson et al

\section{Human microvascular endothelial cells are sensitive to IGF-I but resistant to insulin at the receptor level}

\section{G. S. Johansson, S. I. Chisalita and H. J. Arnqvist}

Linköping University, Faculty of Health Sciences, Department of Clinical and Experimental medicine, Division of Cell Biology $10^{\text {th }}$ floor, S-581 85 Linköping, Sweden

Linköping University, Faculty of Health Sciences, Diabetes Research Centre, S-581 85

Linköping, Sweden

To whom correspondence should be addressed:

Git Johansson

Linköping University,

Faculty of Health Sciences,

Department of Clinical and Experimental medicine,

Division of Cell Biology $10^{\text {th }}$ floor,

S-581 85 Linköping,

Sweden

Phone: +46 13222789

Fax: +46 13224273

E-mail: git.johansson@ibk.liu.se 
MCE-D-08-00188

Human microvascular endothelial cells are sensitive to IGF-I but resistant to insulin at the receptor level
REVISED MANUSCRIPT

Git Johansson et al

\section{Keywords}

IGF-I receptor, insulin receptor, hybrid receptor, RT-PCR, western blot, thymidine incorporation

\section{Summary}

Human microvascular endothelial cells (HMVEC) are sensitive to IGF-I but insulin resistant and express several times more IGF-I receptors (IGF-IR) than insulin receptors (IR). Our aim was to investigate the mechanism of this insulin resistance in cultured HMVEC by studying receptor activation and signal propagation downstream.

The IGF-IR $\beta$-subunit and the IR $\beta$-subunit were detected and found to co-precipitate. IRA was the major IR isoform expressed in HMVEC. IGF-I $10^{-9}-10^{-8} \mathrm{M}$ phosphorylated its cognate receptor $\beta$-subunit. IGF-I also phosphorylated the IR $\beta$-subunit at $10^{-9} \mathrm{M}$. Phosphorylation of insulin receptor substrate 1 was obtained by IGF-I $10^{-9}-10^{-8} \mathrm{M}$. Akt was phosphorylated by IGF-I at $10^{-8}-10^{-7} \mathrm{M}$ and by insulin $10^{-7} \mathrm{M}$. IGF-I at $10^{-8}-10^{-6} \mathrm{M}$ significantly increased DNA synthesis. We conclude that microvascular endothelial cells are sensitive to IGF-I but resistant to insulin due to a preponderance of IGF-I receptors and sequestration of insulin receptors into insulin/IGF-I hybrid receptors. 
MCE-D-08-00188

Human microvascular endothelial cells are sensitive to IGF-I but resistant to insulin at the receptor level
REVISED MANUSCRIPT

Git Johansson et al

\section{Introduction}

Vascular complications in diabetes largely affect the microcirculation, and the integrity and function of the endothelium is an important factor in the development of these complications (Kim et al., 2006, Pambianco et al., 2006). In diabetes circulating insulin levels as well as the insulin-like growth factor (IGF) system are altered (Bereket et al., 1999, Delafontaine et al., 2004, Hedman et al., 2004). Insulin and IGF-I initiate their biological effects by binding to their cognate cell surface receptors; the IGF-I receptor (IGF-IR) and the insulin receptor (IR), which are highly homologous (Siddle et al., 2001). Both belong to the tyrosine kinase family having a tetrameric structure formed by two $\alpha \beta$-dimers consisting of an extracellular $\alpha$-subunit and a transmembrane $\beta$-subunit (Siddle et al., 2001). Due to their structural similarity, insulin and IGF-I can cross-react with each other's receptor but with a 100-1000fold lower affinity than to their own receptor. The IR exists in two isoforms, IRA which lacks exon 11 and IRB with exon 11. These have been shown to have different binding affinities for IGF-I and IGF-II (Frasca et al., 1999). The IR and the IGF-IR can also heterodimerize to form hybrid receptors, consisting of one IR $\alpha \beta$-dimer and one IGF-IR $\alpha \beta$-dimer, shown to have a binding affinity similar to the IGF-IR, $i$ e to bind IGF-I, but not insulin, with high affinity (Soos and Siddle, 1989).

We have previously reported that human microvascular endothelial cells (HMVEC) are sensitive to IGF-I but insensitive to insulin (Chisalita and Arnqvist, 2004). HMVEC express both IR and IGF-IR but IGF-IR are several times more abundant than IR (Chisalita and Arnqvist, 2004). In human macrovascular endothelial cells IR and IGF-IR have been found to form hybrid insulin/IGF-I receptors (Chisalita et al., 2006, Nitert et al., 2005) which may be of importance for insulin sensitivity. The aim of this study was to investigate at what level insulin resistance occurs in HMVEC. We therefore studied the dose-response of IGF-I and insulin with regard to receptor activation, downstream signalling and biological effect. The relative mRNA abundance for the IR isoform A compared to the IR isoform B, and the presence of hybrid receptors were also determined since this may be of importance for insulin sensitivity.

\section{Materials and Methods}

\subsection{Cell culture}

Primary human microvascular endothelial cells (HMVEC) isolated from adult dermis were provided by Clonetics ${ }^{\mathrm{TM}}$ (San Diego, USA). Cells were cultured in EBM-2 medium supplemented with EGM-2 Single Quots (Clonetics ${ }^{\mathrm{TM}}$ ). All experiments were performed on near-confluent cultures from passages 3-9 made quiescent by incubation for 18-24 $\mathrm{h}$ in serum-free EBM-2 medium.

\subsection{Quantitative RT-PCR}

Quantitative real time RT-PCR analysis was performed in order to compare the relative abundance of mRNA for the two IR isoforms in HMVEC. The procedure was performed as described previously (Chisalita and Arnqvist, 2004). The following primers and probes purchased from SGS (Scandinavian Gene Synthesis AB, Köping, Sweden), were used: IRA forward primer: 5'-GTTTAGGAAGACGTTTGAGGATT -3', IRA reverse primer: 5'TCACATTCCCAACATCGCCA-3', IRA receptor probe: 5'- (FAM)CACACGTGGTTTTCGTCCCCAGGCCAT (TAMRA)- 3'; IRB primer: 5'- 
ATTACCTGCACAACGTGGTTTTC -3', IRB reverse primer: 5'GGACCTGCGTTTCCGAGA T-3' and IRB probe: 5' - (FAM)AACCTCTTCAGGCACTGGTGCCGAG (TAMRA)-3'.

\subsection{Receptor phosphorylation and cell lysis}

The cells were stimulated for $10 \mathrm{~min}$ at $37^{\circ} \mathrm{C}$ with recombinant human IGF-I (Gropep, Adelaide, Australia) or recombinant human insulin (SIGMA-Aldrich Sweden AB, Stockholm, Sweden) at concentrations $10^{-10}-10^{-8} \mathrm{M}$ or $10^{-10}-10^{-7} \mathrm{M}$. Stimulation with VEGF was used as a positive control for extracellular kinases 1 and 2 (ERK 1/2). In experiments on receptors and insulin receptor substrate 1 (IRS-1) phosphorylation, the cells were

preincubated with $50 \mu \mathrm{M}$ sodium vanadate on ice for $30 \mathrm{~min}$. After stimulation the cells were solubilized with ice-cold cell lysis buffer [20 mM Tris, $150 \mathrm{mM} \mathrm{NaCl}, 5 \mathrm{mM}$ EDTA, $0.5 \%$ (wt/vol) sodium deoxycholate, and $0.5 \%$ (vol/vol) Triton X-100, $\mathrm{pH} 7.5]$ supplemented with $1 \mathrm{mM}$ phenylmethylsulfonyl fluoride, $1.5 \mathrm{mg} / \mathrm{ml}$ leupeptin, $1.5 \mathrm{mg} / \mathrm{ml}$ aprotinin and $1 \mu \mathrm{M}$ sodium vanadate for $30 \mathrm{~min}$ on ice (all chemicals from Sigma-Aldrich),. The lysed cells were scraped and further disrupted by passage through a syringe needle, followed by centrifugation at $12000 \mathrm{x}$ g for $15 \mathrm{~min}$ at $4^{\circ} \mathrm{C}$ to pellet cell debris. The lysate supernatants were stored at $70^{\circ} \mathrm{C}$ pending further analysis. The protein content of the lysates was determined using the bicinchoninic acid protein method (Pierce, Rockford, IL).

\subsection{Immunoprecipitation}

Primary antibodies used for immunoprecipitation (IP) included rabbit polyclonal anti-IR $\beta$-subunit (C-19), rabbit polyclonal anti-IGF-IR $\beta$-subunit (C-20) and rabbit polyclonal antiIRS-1 (C-20) from Santa Cruz Biotechnology (Santa Cruz, USA). The lysates were immunoprecipitated as described previously using protein A-Sepharose (Pharmacia-Upjohn, Uppsala, Sweden) to collect the immune complexes (Johansson and Arnqvist, 2006). The receptor antibodies used in this study have previously been shown to be highly specific for the $\beta$-subunits of the IR and IGF-IR, respectively (Johansson and Arnqvist, 2006). The previous study was, however, performed on cell lysate from vascular smooth muscle cells of rat origin, so, in order to assure the specificity of the antibodies in human endothelial cell lysate as well, we performed the same reducing experminents prior to IP in HMVEC lysate, confirming earlier results (data not shown).

\subsection{SDS-PAGE and western blot analysis}

Levels of phoshporylated insulin and IGF-I receptor $\beta$-subunit proteins and signalling molecules were analyzed with SDS-PAGE and Western blot analysis using standard methods. Primary antibodies used for immunoblotting studies included monoclonal mouse anti-PY20 antibody and rabbit polyclonal antibodies for IR $\beta$-subunit (C-19), IGF-IR $\beta$-subunit (C-20), IRS-1 (C-20) and phospho-Akt 1/2/3 (Thr308), all purchased from Santa Cruz Biotechnology. Rabbit polyclonal antibodies for total Akt, phospho-ERK 1/2 (Thr202/Tyr204) and total ERK 1/2 were obtained from Cell Signalling (Boston, USA). The membranes were incubated with a horseradish peroxidase (HRP)-conjugated antibody, either HRP-conjugated sheep anti-mouse antibody (Amersham Biosciences, Uppsala, Sweden) or HRP-conjugated goat anti-rabbit antibody obtained from Zymed (San Francisco, USA). The proteins were then visualized with enhanced chemiluminescence (ECL) detection reagents and exposure to ECL Hyperfilm ${ }^{\mathrm{TM}}$, both from Amersham Biosciences. After detection of phosphorylated receptor $\beta$-subunit or signalling molecule, the membranes were stripped and 
reprobed to measure the total (both phosphorylated and unphosphorylated) amount of the specific protein. All membranes were scanned with a LAS1000 camera (Image-Guage, Fujifilm, Tokyo, Japan) with subsequent densitometric evaluation using Multi Gauge Version 3.0 (FujiFilm, Tokyo, Japan). Data were registered as per cent phosphorylated/total protein of maximum phosphorylated/total protein on each membrane, and the results presented as the mean of 3 - 4 experiments.

\section{$2.6\left[6-{ }^{3} \mathrm{H}\right]$ thymidine incorporation}

DNA synthesis was quantified as $\left[6-{ }^{3} \mathrm{H}\right]$ thymidine (Amersham Biosciences) incorporation into DNA. The cells were grown on 6-well plates until near confluent when they were serum starved for $18-20 \mathrm{~h}$ in serum-free EBM-2 medium. They were then stimulated for 18-20 h with hormones at indicated concentrations in fresh serum-free EBM-2 medium, and then incubated for a further $3 \mathrm{~h}$ with $\left[6-{ }^{3} \mathrm{H}\right]$ thymidine $(1 \mu \mathrm{Ci} / \mathrm{ml})$. The cells were washed free of medium with PBS, and the DNA precipitated with ice-cold $5 \%$ (wt/vol) trichloroacetic acid for $15 \mathrm{~min}$ at $4^{\circ} \mathrm{C}$. The cells were then solubilized in $1.0 \mathrm{ml}$ of $0.1 \mathrm{~mol} / \mathrm{l}$ potassium hydroxide for $1-2 \mathrm{~h}$ at room temperature. $0.7 \mathrm{ml}$ of cell solution was added to $4 \mathrm{ml}$ of UltimaGold scintillation fluid and the radioactivity measured in a liquid scintillation counter (Rackbeta 1217).

\subsection{Statistical analysis}

Statistical comparisons of means \pm SEM were performed using SPSS 12.0.1 for Windows (Chicago, IL) with one-way ANOVA and post hoc testing with Dunnett t-test (2sided). A $p$ value of 0.05 was considered statistically significant.

\section{Results}

\subsection{Quantification of IRA and IRB $m R N A$}

In HMVEC, expression of receptor mRNA for the IR isoforms IRA and IRB, was demonstrated by real time RT-PCR. The relative abundance of IRA mRNA to IRB mRNA expression in HMVEC was approximately 7 times higher ( $p<0.01$ ) (Fig. 1).

\subsection{Presence of receptor co-precipitation}

The cell lysates were analyzed by IP and SDS-PAGE. After IP with the IGF-IR $\beta$-subunit specific antibody we detected a band at the level of the $97.4 \mathrm{kDa}$ molecular marker, which corresponds to the molecular weight of the IGF-IR $\beta$-subunit (Fig. 2A). When the membrane was stripped and reprobed with the IR $\beta$-subunit specific antibody a band at a clearly lower position was detected, corresponding to the IR $\beta$-subunit at $95 \mathrm{kDa}$ (Fig. 2C). After IP with the IR $\beta$-subunit specific antibody bands at the same levels were detected with the specific IR (Fig. 2D) and IGF-IR antibodies (Fig. 2B). This implies co-precipitation of the IGF-IR $\beta$-subunit and the IR $\beta$-subunit.

\subsection{Detection of phosphorylated receptors}

Phosphorylation of the different receptors was studied by detecting phosphorylated tyrosine residues on the immunoprecipitated receptor $\beta$-subunits using PY20 antibody. As 
shown in Figure 3A significant phosphorylation of the IGF-IR $\beta$-subunit was obtained by IGF-I stimulation at concentrations $10^{-9}-10^{-8} \mathrm{M}$ compared to baseline. Phosphorylation of the IR $\beta$-subunit was obtained by stimulation with IGF-I $10^{-9}-10^{-8} \mathrm{M}$ compared to baseline (see Fig. 3B).

\subsection{Detection of intracellular substrates phosphorylated downstream}

To further study the biological effects downstream of the activated receptors we investigated the phosphorylation of IRS-1, ERK 1/2 and Akt (also known as protein kinase B). Phosphorylation of IRS-1 was detected with PY20 and was obtained by IGF-I at concentrations $10^{-9}-10^{-8} \mathrm{M}$ compared to baseline, as seen in Figure 4A. Akt was significantly phosphorylated compared to baseline at threonine 308 by IGF-I stimulation at concentrations $10^{-8}-10^{-7} \mathrm{M}$ and insulin $10^{-7} \mathrm{M}$ (Fig. 4B). ERK $1 / 2$ phosphorylation at threonine 202 and tyrosine 204 was not significantly higher than baseline, as shown in Fig. 4C.

\subsection{Effects on cell proliferation}

The effect of IGF-I and insulin on cell proliferation was studied by $\left[6-{ }^{3} \mathrm{H}\right]$ thymidine incorporation into DNA. $\left[6-{ }^{3} \mathrm{H}\right]$ thymidine incorporation was significantly increased from baseline in cells stimulated with IGF-I $10^{-8}-10^{-6} \mathrm{M}$, with maximum levels reached at $10^{-8} \mathrm{M}$, whereas insulin stimulation did not show any significant increase from baseline, although an increase in effect could be seen at $10^{-8} \mathrm{M}$ (see Fig. 5). Data are expressed as per cent above control (unstimulated) cell radioactivity.

\section{Discussion}

We studied the effects of insulin and IGF-I on microvascular endothelial cells at the receptor level and further downstream. Stimulation with IGF-I or insulin at both physiological and supraphysiological concentrations revealed that IGF-I at $10^{-9}-10^{-8} \mathrm{M}$ phosphorylated its cognate receptor as well as the IR, indicating activation at physiologically relevant concentrations (Frystyk et al., 1994). Co-precipitation of the IGF-IR $\beta$-subunit and the IR $\beta$-subunit, and the phosphorylation of IR $\beta$-subunits at even low IGF-I concentration, suggests the presence of hybrid insulin/IGF-I receptors (Chisalita et al., 2006, Johansson and Arnqvist, 2006, Nitert et al., 2005). Receptor activation by IGF-I was followed by downstream signalling and also increased DNA-synthesis. In contrast insulin $10^{-9}-10^{-8} \mathrm{M}$ did not activate the IR, IRS-1, Akt or ERK 1/2 and had no significant effect on DNA-synthesis. This suggests that HMVEC already exhibits insulin resistance at the receptor level.

It is conceivable that both a reduction in the number of IR and the presence of hybrid insulin/IGF-I receptors contribute to insulin resistance in HMVEC. The specific binding of insulin in HMVEC is several times lower than the specific binding of IGF-I indicating a lower number of homodimeric IR compared to IGF-IR or insulin/IGF-I hybrid receptors (Chisalita and Arnqvist, 2004). For high affinity binding of insulin to IR to occur, binding to both receptor $\alpha$-subunits is necessary (De Meyts and Whittaker, 2002, Ward et al., 2007) whereas IGF-I needs only one IGF-IR $\alpha$-subunit to bind with high affinity. This probably explains why insulin/IGF-I hybrid receptors have a low affinity for insulin but bind IGF-I with the same high affinity as IGF-I homodimers. However, the IR $\alpha \beta$-dimer can be crossactivated through activation of the IGF-IR $\alpha \beta$-dimer in the hybrid receptor (Ward et al., 2007), as was also shown in this study. The formation of hybrid receptors is regulated by a process of random assembly determined by the molar proportion of receptors, i e the less 
abundant receptor will, to a large extent, be incorporated into hybrid insulin/IGF-I receptor (Pandini et al., 1999). In osteoblasts, a cell type with both IGF-IR and IR, and containing insulin/IGF-I hybrid receptors, disruption of the IGF-IR was found to enhance insulin signalling and action indicating that the insulin-generated signal was tempered through interactions with the IGF-IR (Fulzele et al., 2007). Correspondingly, sequestration of insulin receptors into insulin/IGF-I hybrid receptors in HMVEC probably makes the cells insulin resistant.

We analyzed the gene expression of insulin receptor isoforms IRA and IRB, and found IRA to be $\sim 7$ times more prevalent than IRB, indicating that IRA in HMVEC, as in coronary artery endothelial cells (Chisalita et al., 2006), is the dominating isoform. A difference in binding characteristics depending on the incorporated IR halfdimer, IRA or IRB, has been reported (Pandini et al., 2002), but recent studies suggest that both types of hybrid receptors have the same affinity for IGF-I and insulin (Benyoucef et al., 2007, Slaaby et al., 2006). The lack of insulin effect on DNA-synthesis in HMVEC is in agreement with our previous observation (Chisalita and Arnqvist, 2004) together with several other reports on microvascular cells (Artwohl et al., 2007, Giannini et al., 2001) suggesting that human microvascular endothelial cells are insulin resistant. Because of the cross-reactivity of insulin and IGF-I at high concentrations it is very important to use physiological or near physiological concentrations of the peptides when studying insulin and IGF-I effects in vitro on cells that express both IR types and IGF-IR, and also to make sure of which receptor is activated. Several studies demonstrating insulin effects on vascular cells have used insulin concentrations which could well cross-react with the IGF-I receptor (Salt et al., 2003, Zeng and Quon, 1996).

In this and our previous report (Chisalita and Arnqvist, 2004) low concentrations of IGF-I were found to stimulate DNA-synthesis in HMVEC. Other studies on microvascular endothelial cells suggest that HMVEC as well as glomerular (Giannini et al., 1999) and retinal microvascular endothelial cells (Giannini et al., 2001) are very sensitive to IGF-I indicating a physiological function of IGF-I.

Our results were obtained on cultured endothelial cells and it is possible that the phenotype may differ between cultured cells and cells in intact vascular tissue. However, in human umbilical vein endothelial cells the ratio of IGF-IR to IR was similar in cultured and freshly isolated cells (Nitert et al., 2005). The function of IGF-I in intact vascular tissue has been studied in vivo, where the infusion of IGF-I in the human forearm model has been shown to increase blood flow (Pendergrass et al., 1998). Furthermore, in patients with diabetes the IGF system is dysregulated with low circulating IGF-I levels and changes in the IGF-binding proteins (Hedman et al., 2004) and it is possible that these changes affect the function of microvascular endothelial cells (Tooke et al., 1996).

In conclusion, due to a preponderance of IGF-I receptors and sequestration of insulin receptors into insulin/IGF-I hybrid receptors, microvascular endothelial cells are sensitive to IGF-I but are insulin resistant.

\section{References}

Artwohl, M., Brunmair, B., Furnsinn, C., Holzenbein, T., Rainer, G., Freudenthaler, A., Porod, E. M., Huttary, N. \& Baumgartner-Parzer, S. M., 2007. Insulin does not regulate glucose transport and metabolism in human endothelium. Eur J Clin Invest. 37, 643-50.

Benyoucef, S., Surinya, K. H., Hadaschik, D. \& Siddle, K., 2007. Characterisation of insulin/IGF hybrid receptors: contributions of the insulin receptor L2 and Fn1 domains 
and the alternatively spliced exon 11 sequence to ligand binding and receptor activation. Biochem $\mathrm{J}$.

Bereket, A., Lang, C. H. \& Wilson, T. A., 1999. Alterations in the growth hormone-insulinlike growth factor axis in insulin dependent diabetes mellitus. Horm Metab Res. 31, 172-81.

Chisalita, S. I. \& Arnqvist, H. J., 2004. Insulin-like growth factor I receptors are more abundant than insulin receptors in human micro- and macrovascular endothelial cells. Am J Physiol Endocrinol Metab. 286, E896-901.

Chisalita, S. I., Nitert, M. D. \& Arnqvist, H. J., 2006. Characterisation of receptors for IGF-I and insulin; evidence for hybrid insulin/IGF-I receptor in human coronary artery endothelial cells. Growth Horm IGF Res. 16, 258-66.

De Meyts, P. \& Whittaker, J., 2002. Structural biology of insulin and IGF1 receptors: implications for drug design. Nat Rev Drug Discov. 1, 769-83.

Delafontaine, P., Song, Y. H. \& Li, Y., 2004. Expression, regulation, and function of IGF-1, IGF-1R, and IGF-1 binding proteins in blood vessels. Arterioscler Thromb Vasc Biol. 24, 435-44.

Frasca, F., Pandini, G., Scalia, P., Sciacca, L., Mineo, R., Costantino, A., Goldfine, I. D., Belfiore, A. \& Vigneri, R., 1999. Insulin receptor isoform A, a newly recognized, highaffinity insulin-like growth factor II receptor in fetal and cancer cells. Mol Cell Biol. $19,3278-88$.

Frystyk, J., Skjaerbaek, C., Dinesen, B. \& Orskov, H., 1994. Free insulin-like growth factors (IGF-I and IGF-II) in human serum. FEBS Lett. 348, 185-91.

Fulzele, K., Digirolamo, D. J., Liu, Z., Xu, J., Messina, J. L. \& Clemens, T. L., 2007. Disruption of the insulin-like growth factor type 1 receptor in osteoblasts enhances insulin signalling and action. J Biol Chem. 282, 25649-58.

Giannini, S., Cresci, B., Pala, L., Ciucci, A., Franchini, A., Manuelli, C., Fujita-Yamaguchi, Y., Cappugi, P., Zonefrati, R. \& Rotella, C. M., 2001. IGFBPs modulate IGF-I- and high glucose-controlled growth of human retinal endothelial cells. J Endocrinol. 171, 273-84.

Giannini, S., Cresci, B., Pala, L., Ciucci, A., Manuelli, C., Fujita-Yamaguchi, Y., Cappugi, P. \& Rotella, C. M., 1999. Human glomerular endothelial cells IGFBPs are regulated by IGF-I and TGF-beta1. Mol Cell Endocrinol. 154, 123-36.

Hedman, C. A., Frystyk, J., Lindstrom, T., Chen, J. W., Flyvbjerg, A., Orskov, H. \& Arnqvist, H. J., 2004. Residual beta-cell function more than glycemic control determines abnormalities of the insulin-like growth factor system in type 1 diabetes. $\mathbf{J}$ Clin Endocrinol Metab. 89, 6305-9.

Johansson, G. S. \& Arnqvist, H. J., 2006. Insulin and IGF-I action on insulin receptors, IGF-I receptors, and hybrid insulin/IGF-I receptors in vascular smooth muscle cells. Am J Physiol Endocrinol Metab. 291, E1124-30.

Kim, J. A., Montagnani, M., Koh, K. K. \& Quon, M. J., 2006. Reciprocal relationships between insulin resistance and endothelial dysfunction: molecular and pathophysiological mechanisms. Circulation. 113, 1888-904.

Nitert, M. D., Chisalita, S. I., Olsson, K., Bornfeldt, K. E. \& Arnqvist, H. J., 2005. IGFI/insulin hybrid receptors in human endothelial cells. Mol Cell Endocrinol. 229, 31-7.

Pambianco, G., Costacou, T., Ellis, D., Becker, D. J., Klein, R. \& Orchard, T. J., 2006. The 30-year natural history of type 1 diabetes complications: the Pittsburgh Epidemiology of Diabetes Complications Study experience. Diabetes. 55, 1463-9.

Pandini, G., Frasca, F., Mineo, R., Sciacca, L., Vigneri, R. \& Belfiore, A., 2002. Insulin/insulin-like growth factor I hybrid receptors have different biological 
characteristics depending on the insulin receptor isoform involved. J Biol Chem. 277, 39684-95.

Pandini, G., Vigneri, R., Costantino, A., Frasca, F., Ippolito, A., Fujita-Yamaguchi, Y., Siddle, K., Goldfine, I. D. \& Belfiore, A., 1999. Insulin and insulin-like growth factor-I (IGF-I) receptor overexpression in breast cancers leads to insulin/IGF-I hybrid receptor overexpression: evidence for a second mechanism of IGF-I signaling. Clin Cancer Res. 5, 1935-44.

Pendergrass, M., Fazioni, E., Collins, D. \& Defronzo, R. A., 1998. IGF-I increases forearm blood flow without increasing forearm glucose uptake. Am J Physiol. 275, E345-50.

Salt, I. P., Morrow, V. A., Brandie, F. M., Connell, J. M. \& Petrie, J. R., 2003. High glucose inhibits insulin-stimulated nitric oxide production without reducing endothelial nitricoxide synthase Ser1177 phosphorylation in human aortic endothelial cells. J Biol Chem. 278, 18791-7.

Siddle, K., Urso, B., Niesler, C. A., Cope, D. L., Molina, L., Surinya, K. H. \& Soos, M. A., 2001. Specificity in ligand binding and intracellular signalling by insulin and insulinlike growth factor receptors. Biochem Soc Trans. 29, 513-25.

Slaaby, R., Schaffer, L., Lautrup-Larsen, I., Andersen, A. S., Shaw, A. C., Mathiasen, I. S. \& Brandt, J., 2006. Hybrid receptors formed by insulin receptor (IR) and insulin-like growth factor I receptor (IGF-IR) have low insulin and high IGF-1 affinity irrespective of the IR splice variant. J Biol Chem. 281, 25869-74.

Soos, M. A. \& Siddle, K., 1989. Immunological relationships between receptors for insulin and insulin-like growth factor I. Evidence for structural heterogeneity of insulin-like growth factor I receptors involving hybrids with insulin receptors. Biochem J. 263, 55363.

Tooke, J. E., Morris, S. J. \& Shore, A. C., 1996. Microvascular functional abnormalities in diabetes: the role of the endothelium. Diabetes Res Clin Pract. 31 Suppl, S127-32.

Ward, C. W., Lawrence, M. C., Streltsov, V. A., Adams, T. E. \& Mckern, N. M., 2007. The insulin and EGF receptor structures: new insights into ligand-induced receptor activation. Trends Biochem Sci. 32, 129-37.

Zeng, G. \& Quon, M. J., 1996. Insulin-stimulated production of nitric oxide is inhibited by wortmannin. Direct measurement in vascular endothelial cells. J Clin Invest. 98, 894-8. 
MCE-D-08-00188

REVISED MANUSCRIPT

Human microvascular endothelial cells are sensitive to IGF-I

Git Johansson et al but resistant to insulin at the receptor level

\section{Acknowledgements}

We are grateful to Anna-Kristina Granath for excellent technical assistance. Financial support was obtained from Landstinget Östergotland, the Swedish Medical Research Council (04952), the Swedish Diabetes Association and Barndiabetesfonden. 
MCE-D-08-00188

Human microvascular endothelial cells are sensitive to IGF-I but resistant to insulin at the receptor level
REVISED MANUSCRIPT

Git Johansson et al

\section{Figure legends}

\section{Figure 1}

Gene expression of insulin receptor A (IRA) and insulin receptor B (IRB) isoforms in cultured dermal microvascular cells (HMVEC). IRA and IRB mRNA expression was measured by real time RT-PCR. Grey filled bar represents IRA mRNA and unfilled bar represents IRB mRNA. Data is expressed as amount IRA mRNA relative to IRB mRNA, where IRB was set to 1 . Bars are means $\pm \mathrm{SE}$ of four experiments. $* *=p<0.01$.

\section{Figure 2}

Co-precipitation of IR $\beta$-subunits and IGF-IR $\beta$-subunits in HMVEC. IGF-I receptor (IGFIR) $\beta$-subunit $(97 \mathrm{kDa})$ and insulin receptor (IR) $\beta$-subunit $(95 \mathrm{kDa})$ was detected by Western blot in the same IP using specific IR $\beta$-subunit or IGF-IR $\beta$-subunit antibodies, implying coprecipitation. The figure shows blots after immunoprecipitation (IP) against either IGF-IR $\beta$-subunit (left column, 2A \& 2C) or IR $\beta$-subunit (right column, 2B \& 2D), and immunoblot against the IGF-IR $\beta$-subunit (upper blots, $2 \mathrm{~A} \& 2 \mathrm{~B}$ ) and the IR $\beta$-subunit (lower blots, $2 \mathrm{C} \&$ $2 D)$. Similar results were obtained in three independent experiments.

\section{Figure 3}

Phosphorylation of IR and IGF-IR in HMVEC. Effects of IGF-I and insulin on tyrosine phosphorylation of IGF-IR $\beta$-subunit (Fig 3A) or IR $\beta$-subunit (Fig 3B) in HMVEC were analyzed by immunoprecipitation with an IGF-IR or IR $\beta$-subunit specific antibody and immunoblotting with an anti-phosphotyrosine antibody (PY20). Significant phosphorylation of the IGF-IR $\beta$-subunit compared to baseline was found at IGF-I stimulations at $10^{-9}-10^{-8} \mathrm{M}$, Fig 3A. Phosphorylation of the IR $\beta$-subunit compared to baseline was found at IGF-I stimulations at $10^{-9}-10^{-8} \mathrm{M}$, Fig 3B. Dark grey filled bars represent IGF-I stimulation and light grey filled bars represent insulin stimulation. Data are means from three independent experiments. Data were quantified by densitometry and are expressed as phosphorylated/total protein, fractional of maximal response. $*=p<0.05, * *=p<0.01$.

\section{Figure 4}

Activation of insulin receptor substrate 1 (IRS-1), Akt (PKB) and ERK 1/2 in HMVEC. Effects of IGF-I and insulin on tyrosine phosphorylation of IRS-1 was analyzed by immunoprecipitation of IRS-1 with an IRS-1 antibody and immunoblotting with an antiphosphotyrosine antibody (PY20). Significant phosphorylation of IRS-1 compared to basline was found at IGF-I stimulations at $10^{-9}-10^{-8} \mathrm{M}$, see Fig. 4A. Akt phosphorylation was analyzed using a specific antibody detecting Akt 1/2/3 phosphorylated at threonine 308 . Significant phosphorylation of Akt compared to baseline was found at IGF-I stimulations at $10^{-8}-10^{-7} \mathrm{M}$, insulin $10^{-7} \mathrm{M}$, see Fig. 4B. No significant phosphorylation compared to baseline was observed on ERK 1/2 phosphorylation at threonine 202 and tyrosine 204 (Fig. 4C). Grey filled bars represent IGF-I stimulation and unfilled bars represent insulin stimulation. Data are means from four and eight independent experiments respectively. Data were quantified by 


\section{MCE-D-08-00188}

Human microvascular endothelial cells are sensitive to IGF-I

Git Johansson et al but resistant to insulin at the receptor level

densitometry and are expressed as means of per cent phosphorylated/total protein of maximal response. $*=p<0.05, * *=p<0.01$.

\section{Figure 5}

Effects of IGF-I and insulin on $\left[{ }^{3} \mathrm{H}\right]$ thymidine incorporation into DNA in HMVEC. Grey filled bars represent IGF-I stimulation and unfilled bars represent insulin stimulation. Data are expressed as thymidine incorporation above baseline, and are compared to baseline. Bars are mean $\pm \mathrm{SE}$ of 10 experiments. $*=p<0.05$. 


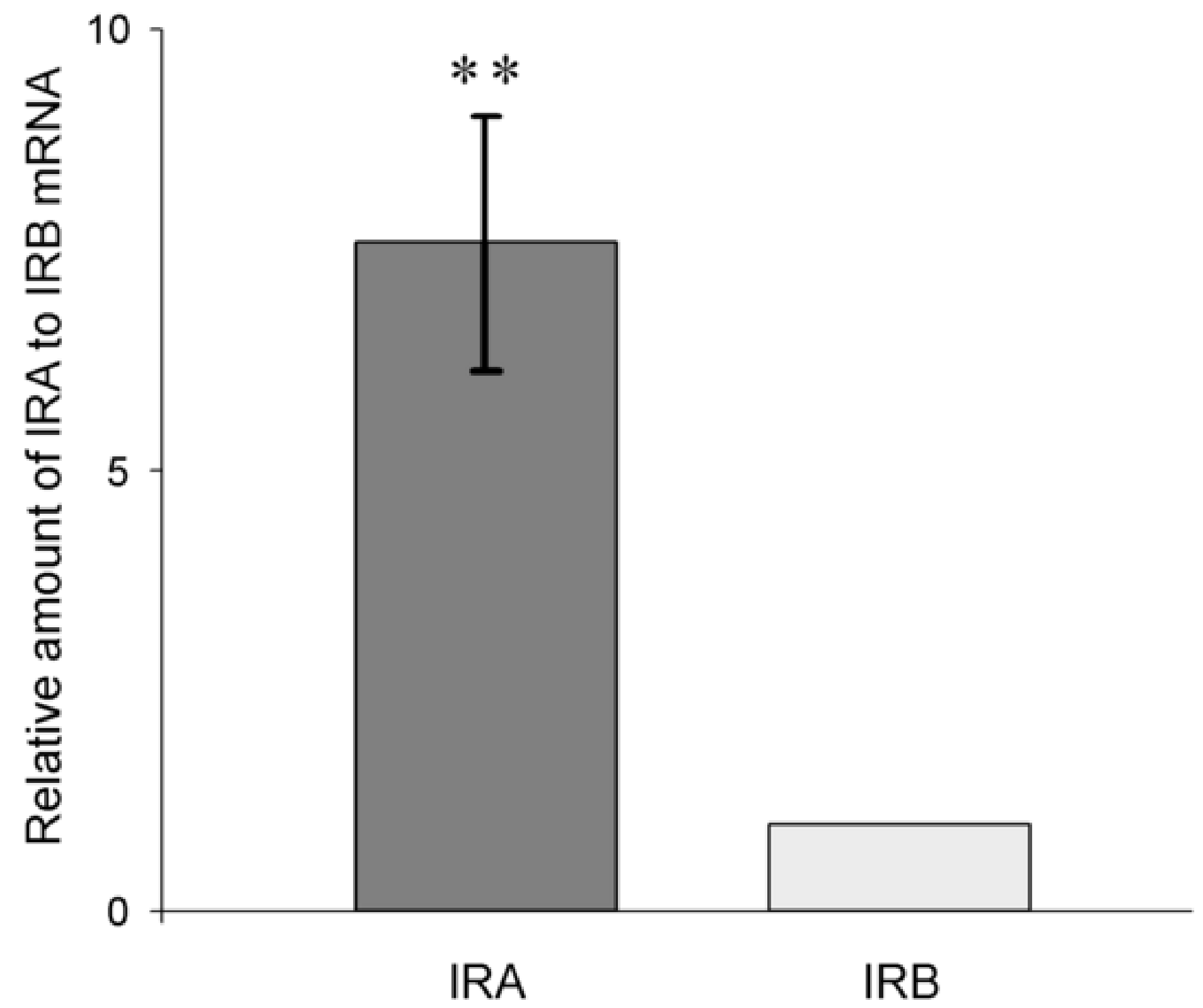

rage 13 or 20 
IP:IGF-IR $\beta$

(A)

IB: IGF-IR $\beta$

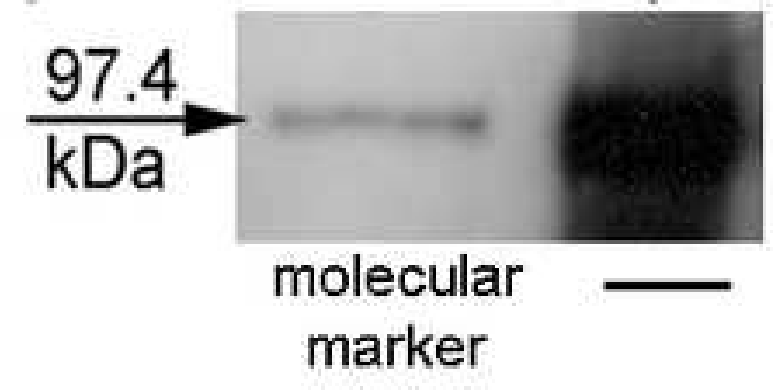

(C)

IB: IR $\beta$

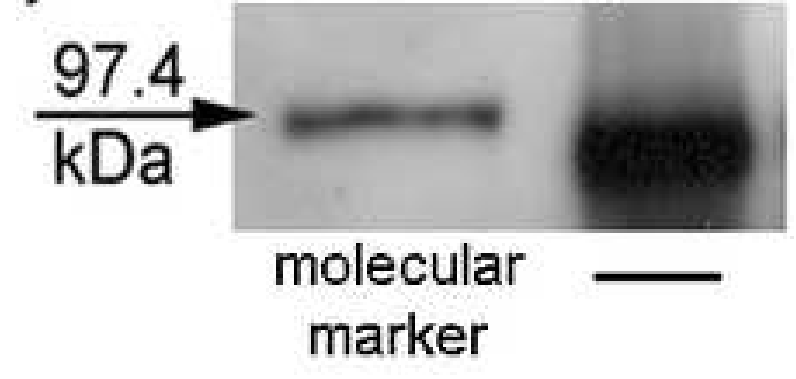

IP: IR $\beta$

(B)

IB: IGF-IR $\beta$

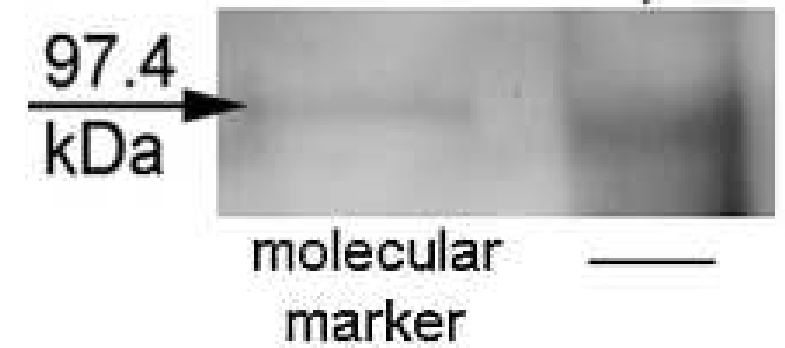

(D)

IB: IR $\beta$

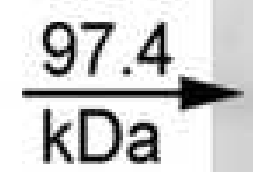

molecular marker 
(A)

IB: PY20

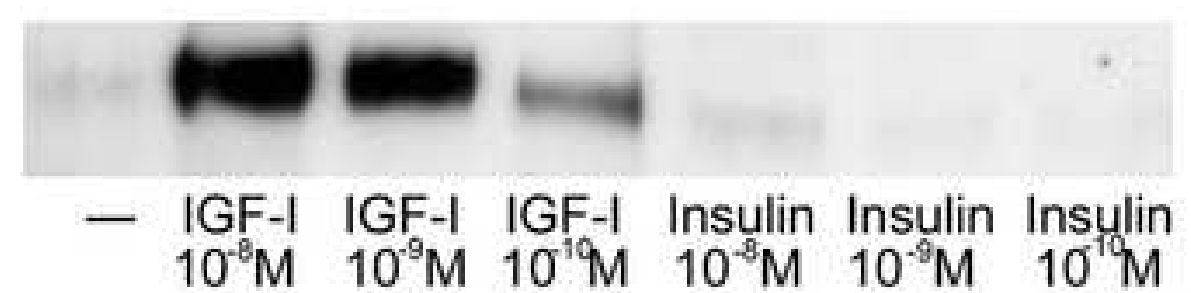

IB: IGF-IR $\beta$

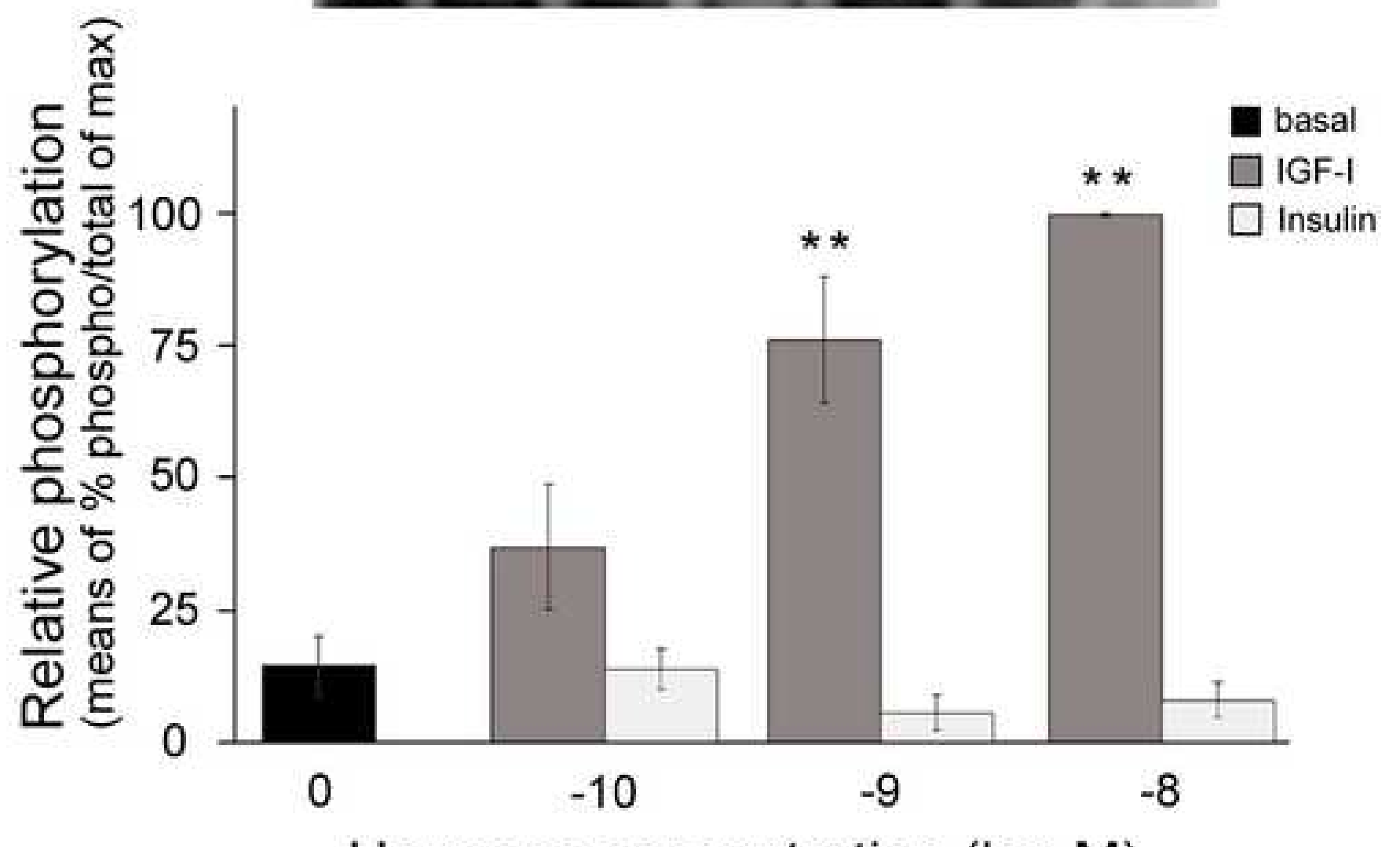

Hormone concentration $(\log M)$ 
(B)

IP: IR $\beta$

IB: PY20

- IGF-I IGF-I IGF-I Insulin Insulin Insulin $\begin{array}{llllll}10^{-8} \mathrm{M} & 10^{-9} \mathrm{M} & 10^{19} \mathrm{M} & 10^{-8} \mathrm{M} & 10^{-9} \mathrm{M} & 10^{-19} \mathrm{M}\end{array}$

IB: IR $\beta$

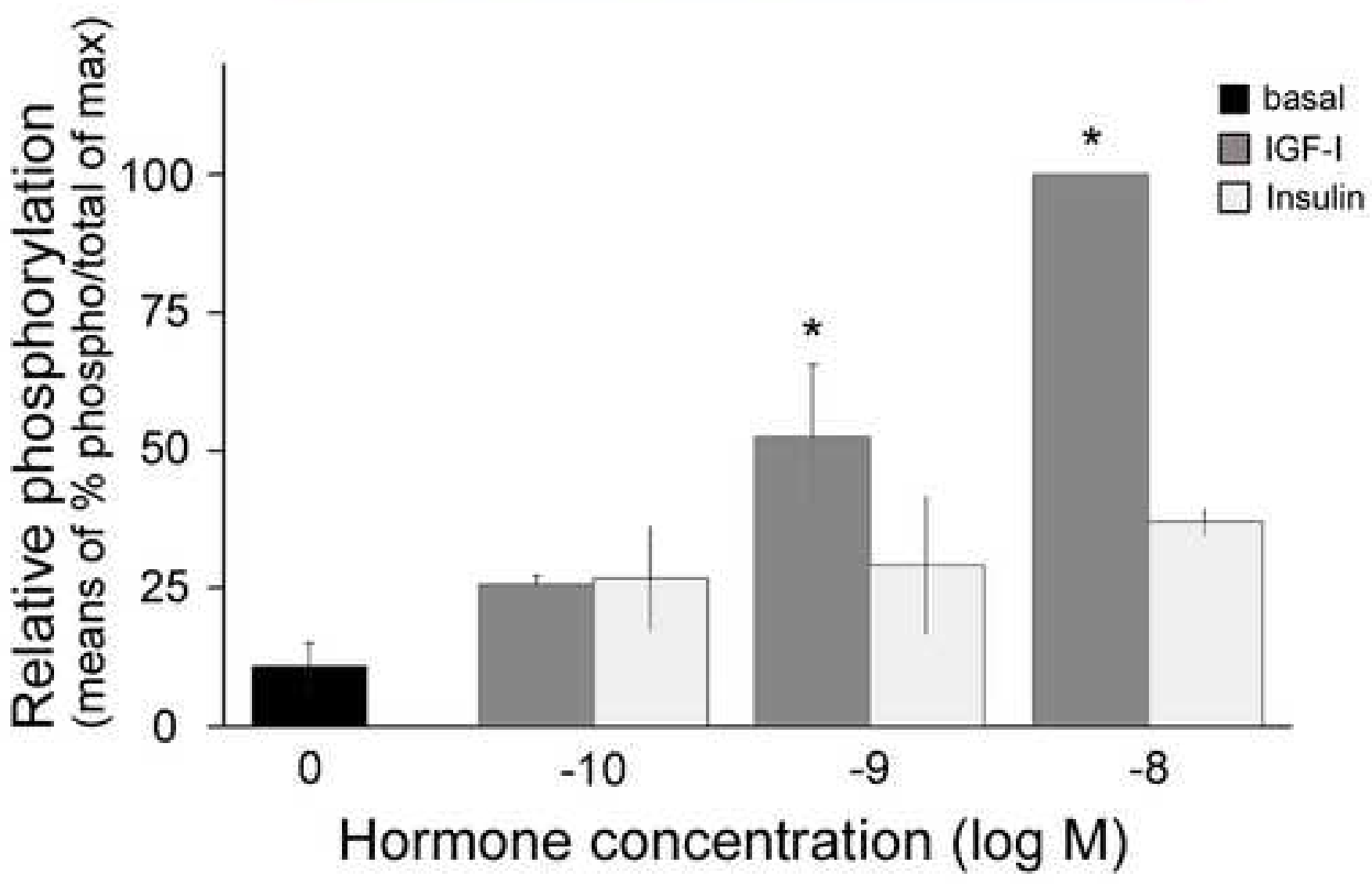




\section{IP: IRS-1}

IB: PY20

- IGF-I IGF-I IGF-I Insulin Insulin Insulin $\begin{array}{llllll}10^{-8} \mathrm{M} & 10^{-9} \mathrm{M} & 10^{-19} \mathrm{M} & 10^{-8} \mathrm{M} & 10^{-9} \mathrm{M} & 10^{19} \mathrm{M}\end{array}$

IB: IRS-1

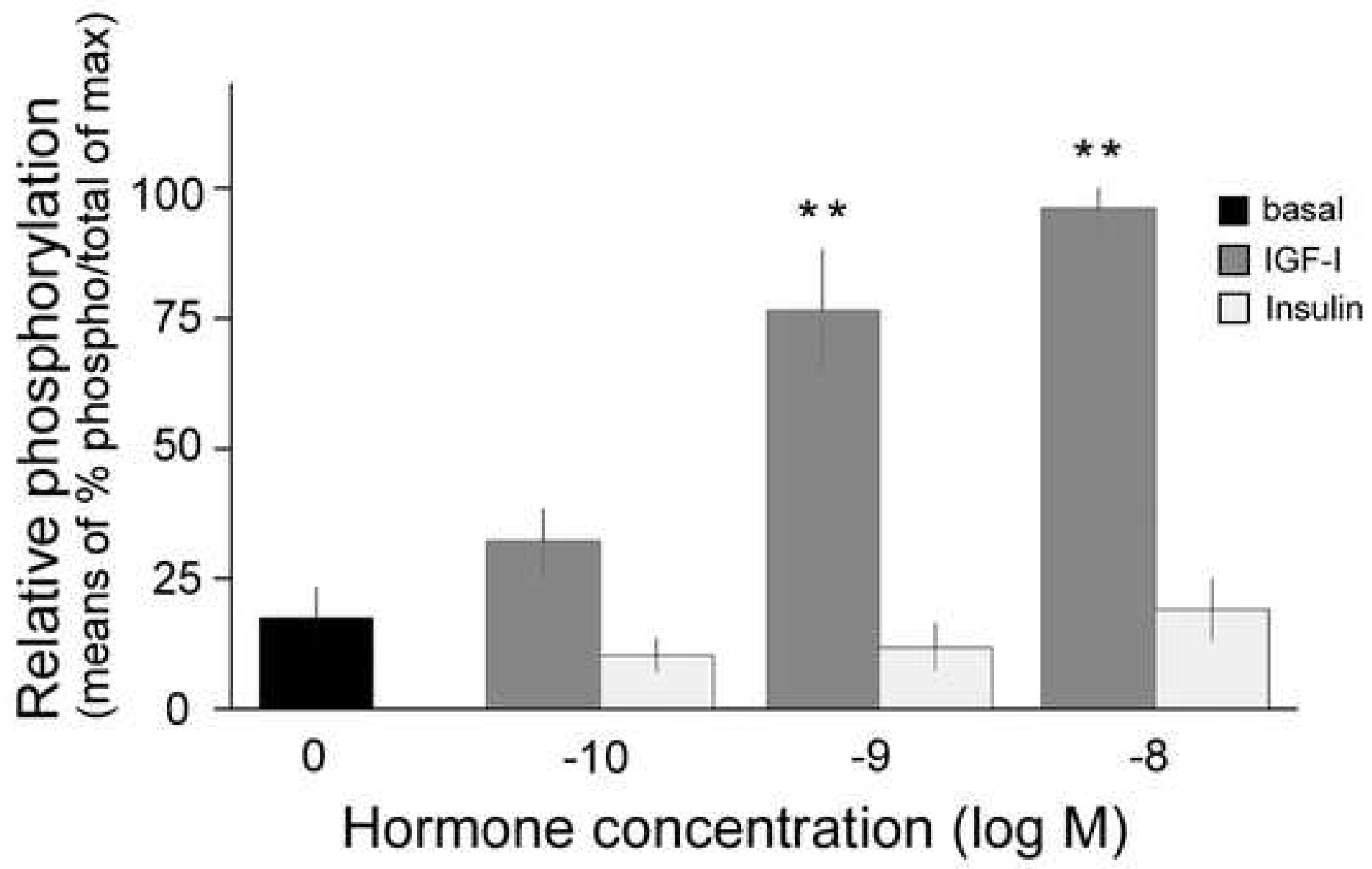


(B)

\section{AKT}

IB: p-AKT

- IGF-| IGF-I IGF-I IGF-I Insulin Insulin Insulin Insulin $\begin{array}{llllllll}10^{-7} \mathrm{M} & 10^{-8} \mathrm{M} & 10^{-9} \mathrm{M} & 10^{-10} \mathrm{M} & 10^{-7} \mathrm{M} & 10^{-8} \mathrm{M} & 10^{-9} \mathrm{M} & 10^{-10} \mathrm{M}\end{array}$

IB: AKT

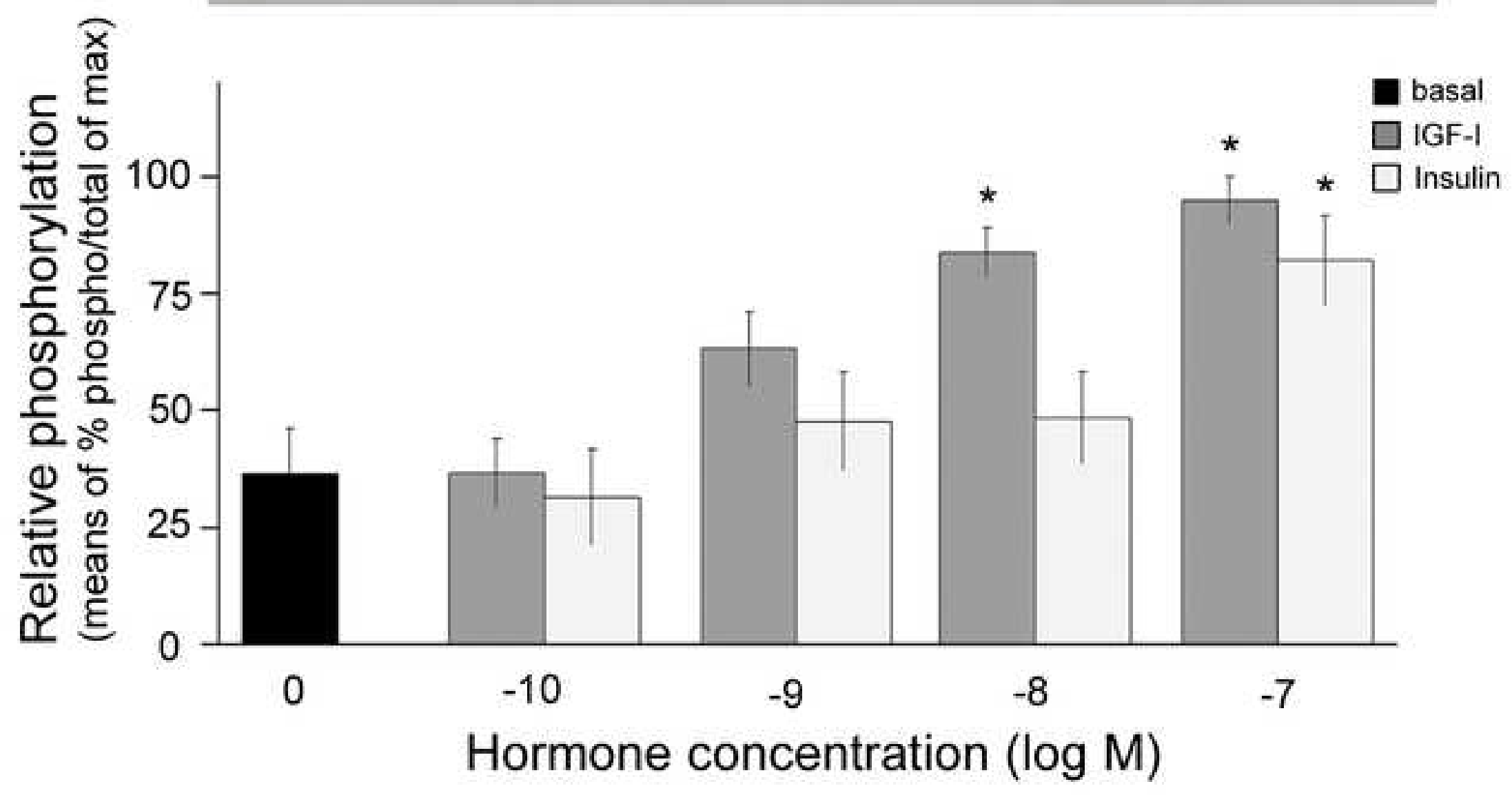




\section{ERK $1 / 2$}

IB: p-ERK $1 / 2$

- IGF-I IGF-I IGF-I IGF-I Insulin Insulin Insulin Insulin $\begin{array}{llllllllll}10^{-7} \mathrm{M} & 10^{-8} \mathrm{M} & 10^{-9} \mathrm{M} & 10^{-10} \mathrm{M} & 10^{-7} \mathrm{M} & 10^{-8} \mathrm{M} & 10^{-9} \mathrm{M} & 10^{-10} \mathrm{M}\end{array}$

IB: ERK $1 / 2$

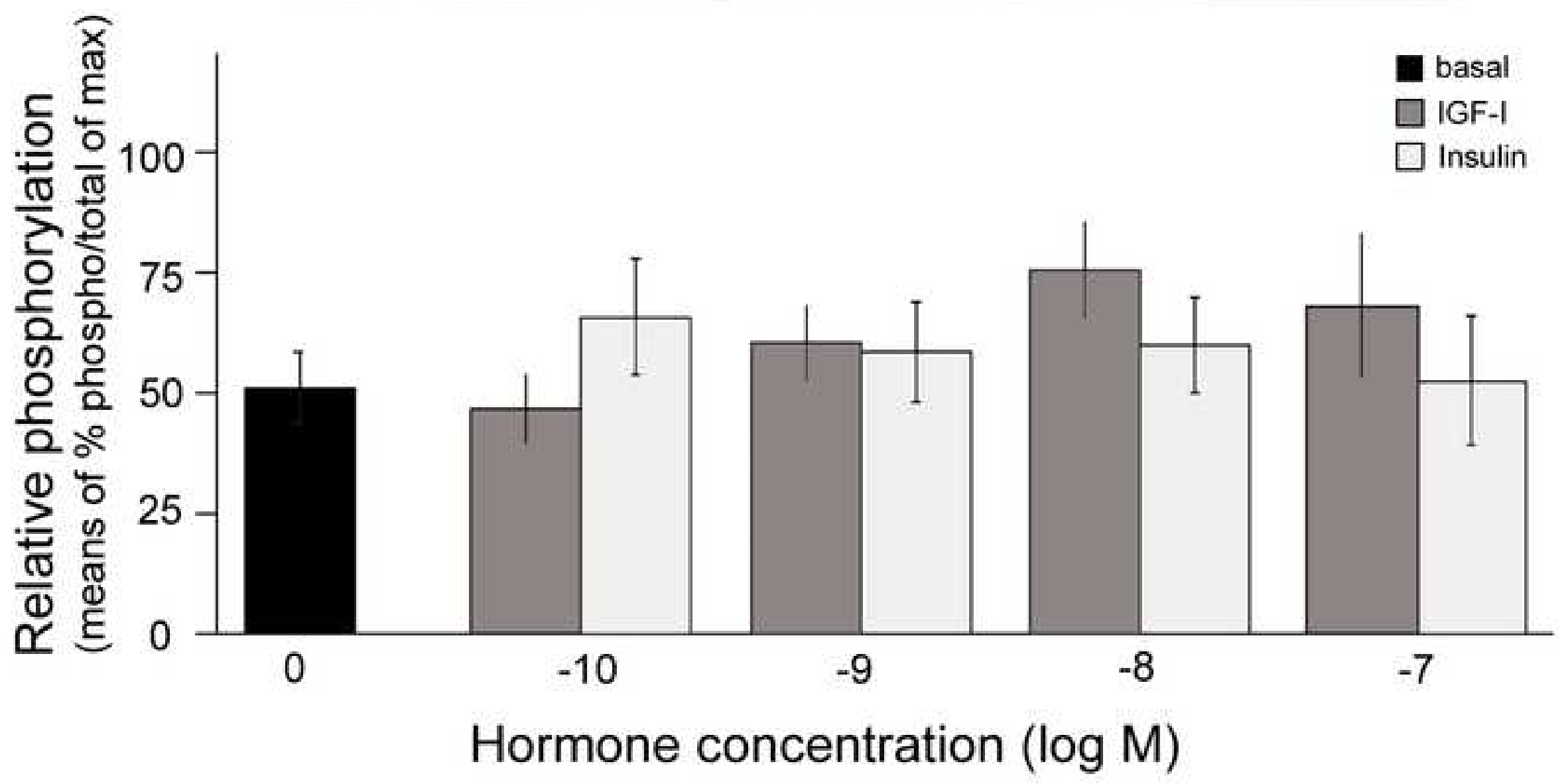

rage $1 y$ or $2 U$ 


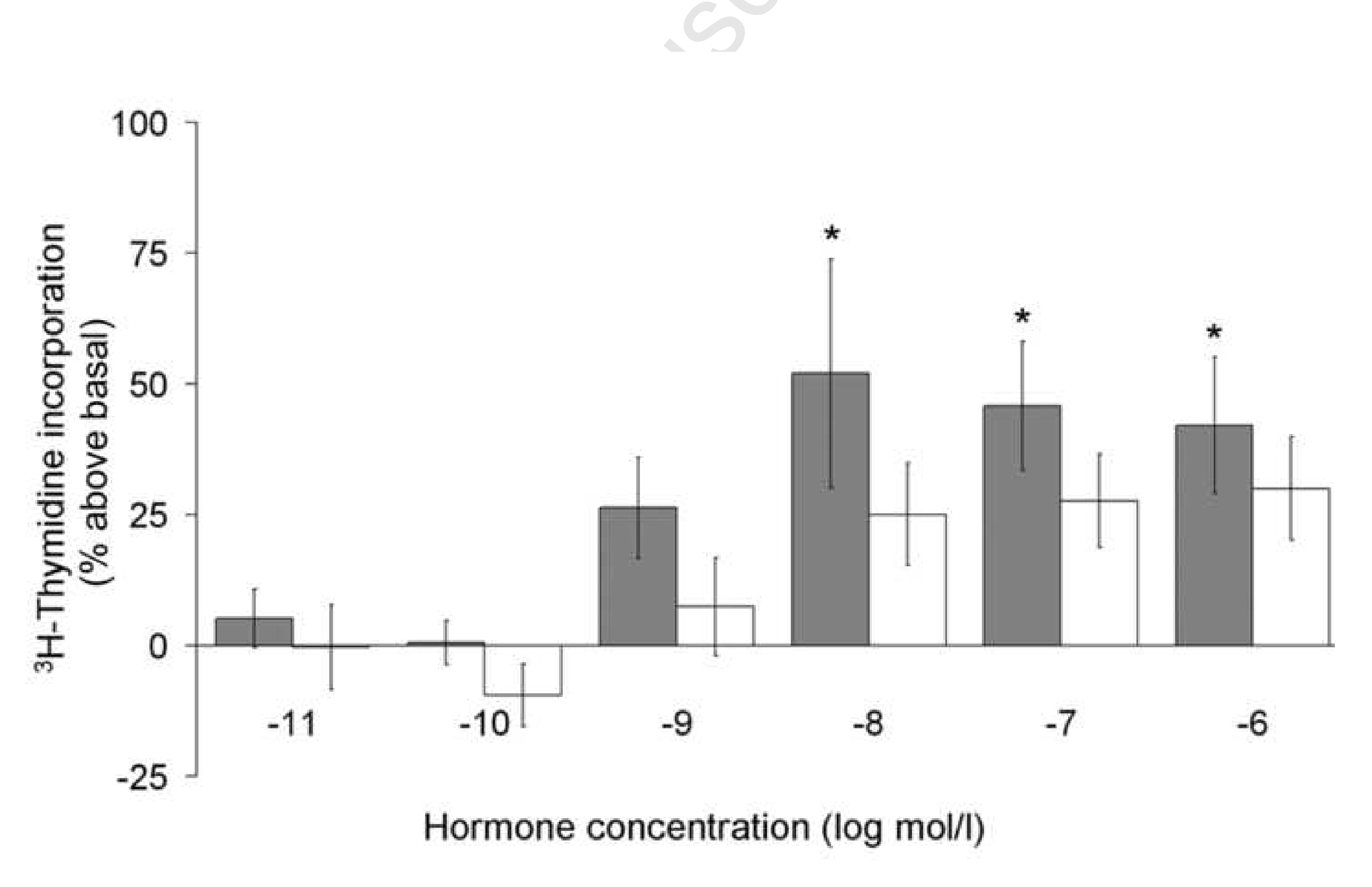

Hormone concentration (log $\mathrm{mol} / \mathrm{l})$

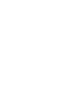

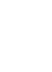

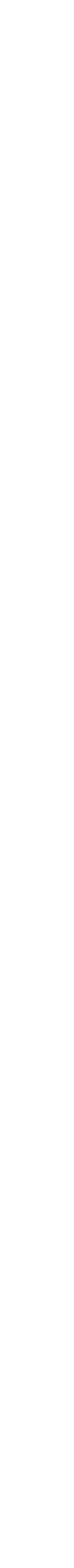

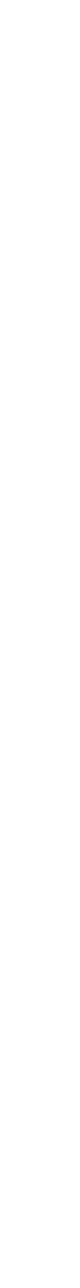

(t)

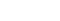
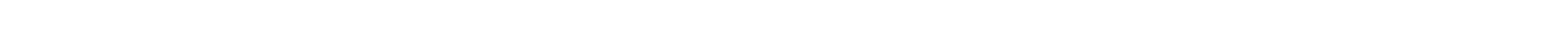

-

